\title{
Introduction: Historicising the Women's Liberation Movement
}

Women's liberation, also now known as 'second wave feminism', is commonly taken to be the upsurge in feminist activism and other feminist practices, agency and organisation in Europe, North America and many other developed countries between the mid 1960s to the mid 1980s. The economic and social context for the women's liberation movement (WLM) was post war affluence, rising living standards and increased educational opportunities. The WLM arose from, and was very much part of, what is termed 'new social movements' of the 1960s, particularly an end to the threat of nuclear war, anti-apartheid, opposition to the Vietnam war and civil rights. Women were frustrated and angry by their continued second class status in the post war world. The WLM produced widespread structural and attitudinal change which had a profound impact on the western world in the late twentieth century. By developing an 'imagined community’ of feminism, women created a new sense of female selfhood. ${ }^{1}$

As Stephanie Gilmore has written, 'if we are to have a feminist future we need a feminist past upon which to stand and build'. ${ }^{2}$ This should not be a 'celebratory' history, but a 'usable past'. It follows then that the notion of recovery is also problematic if it is to be more than celebration. As Janet Floyd suggests in her article, the notion of recovery and appropriation is a sensitive and contentious issue, even regarding the most revered of American feminist foremothers. The history of the WLM has been distorted by media portrayals of 'bra burning' feminists protesting about beauty contests in metropolitan centres such as London and the East coast of the USA, and by an unquestioning acceptance of criticisms of the movement as urban, racist and classist. This ignored the feminist activism of other regions and focussed on white middle class women. Sue Bruley's article on 'Women's Liberation at the Grass Roots', draws attention to the regionality of the WLM by concentrating on the diverse organisation and local activism and engagement of women's liberation in five urban communities across England. Feminist history is a dynamic and contested terrain, and is currently undergoing a reassessment to include a wider range of female agency and a broader range of political starting points for women's work and women's organisations intending to improve the position of women in society. This special edition of Women's History Review contributes to that reassessment of the second wave of feminism. For instance, we understand now that by highlighting the 'black machismo' of the Black Panthers in the US in the 1960s we ignored the fact that two thirds of the membership of the Panthers were women who learned leadership and organising skills which stood them in good stead in the WLM. ${ }^{3}$ As Becky Thomson has argued, the traditional or 'hegemonic' approach to the history of the WLM 'does not recognise the centrality of the feminism of women of color in Second Wave history'. ${ }^{4}$ Entering into this debate in this volume, Say Burgin problematises the relationship of white US feminists to the issue of race. By focussing on white anti- 
imperialist Boston feminists and their conjoining of issues of racism and sexism, Burgin argues against simplistic narratives about race in the WLM. The impact of post colonial discourse has led to a refocused history of the WLM which underlines the importance of 'intersectionality', i.e. the interconnectedness of class, race and gender. ${ }^{5}$ The category 'woman' is not simply a product of gender discourse. To uncover the history of Afro-American, Latina, Asian, West Indian and other minority women in second wave feminism we need a more inclusive definition of feminist activism which would encompass mixed gender organisations where women flourished and brought about real change in these years. ${ }^{6}$

The idea of 'waves' in feminist history has itself been challenged by Nancy Hewitt which has led to a more nuanced, less white dominated and less suffrage based history of the 'first wave' from the 1840 s to the 1920 s. $^{7}$ Beyond the first wave there was a continuing stream of feminist thought and activism. There is no denying, however, that there was a great burst of feminist energy-mass activism, theoretical texts and literature-between the 1960s and 1980s which distinguishes it from the periods both before and after. In the US in 1970 thirteen texts were produced relating in some way to the WLM. ${ }^{8}$ By the mid 1980s in many states the onslaught of neo-liberal right wing policies put feminism back on the defensive. This period needs to be studied as a distinct phenomenon in its own right. The WLM was hugely diverse, impacting differently according to different local circumstances, national and community needs. In Quebec, for instance, feminists saw their feminism as integral to their French Canadian identity. ${ }^{9}$ Many women opted to work within local, autonomous, selfgoverning WLM groups, often with a 'consciousness raising' element. ${ }^{10}$ There were, though, less radical feminist groups in the US such as the National Organisation of Women (NOW) which adopted formal bureaucratic structures. There was a constant tension between institutionalisation and local, autonomous grass roots campaigning; pragmatic realism versus revolutionary idealism. In Canada feminists were ready to accept state funding, whilst many others saw this as being 'co-opted' into the system. For most feminists, paid employment was the route to economic independence, but the long standing maternalist, 'mothering' stream within feminism continued to assert women's right to choose to stay at home and raise their children, on state benefits if necessary. Marks and Little focus on a marginalised group of Canadian mothers who campaigned for welfare support to enable women to choose to be working mothers or stay at home mothers. This was at odds with those feminists who wanted women to assert their equality through their presence in the workplace, and Marks and Little highlight the differences, and different relationships to the WLM, on this issue between liberal, socialist and conservative groups of mothers.

The desire by the media to designate leaders was strongly resisted across the board, 'second wavers' were insistent that there were no 'stars' in the WLM. Transnational influences were very significant. Cheaper foreign travel meant that many American women brought feminist ideas and literature to Europe in the late 1960s, adding impetus to the nascent European WLM. The idea to 'take 
back the night' first happened in the US when a woman was murdered on her way back from work. It spread to Europe and in the late 1970s and early 80s torch-lit, nocturnal 'reclaim the night' marches were held in red light districts all over the UK, often resulting in clashes with 'porn' shop owners and police. ${ }^{11}$ Despite huge diversity in organisational forms, campaigns and chronology, in essence the core aims of the WLM were very similar: economic equality and access to education, affordable child care; freely determined sexuality, an end to sexual violence and the right to control fertility; political and legal equal equality. Of course, these issues are complex and meant different things to different women, often depending on class and ethnicity. Phillida Bunkle explores the impact of grammar school and university education on girls who benefitted from the 1944 Education Act, who used their education to shape the women's movement through the written word or to develop consciousness through their own reading. On the issue of working class women and the WLM, George Stevenson has sought to foreground working women through a history of four women-centred industrial strikes and disputes in Britain. These reveal complex links to the trade union and women's liberation movements, demonstrating intersections between class, race and gender based issues. Women also expressed their feminism creatively through visual media, performance arts and other cultural outlets. This is not simply a peripheral element but an essential aspect of the dynamism of the WLM. Lisa Taylor, a feminist artist, discusses, in her illustrated article, the creative and political environment surrounding her activist print-making, and offers a contemporary reflection upon, and re-evaluation of, her practice from a vantage point of theoretically-informed feminism. Women's culture can be discerned and detected through the artefacts and creativity of the WLM, and Deborah Withers envisages aspects of the WLM as cultural heritage. She argues that, through publicly oriented projects, exhibitions and feminist archives, women's histories of the WLM reveal women's communities, feminist cultural traditions and a multiplicity of voices. Laurel Forster, in her essay, also points to the diversity of feminist voices and perspectives, discernable through the varied ways that women engaged with print cultures. A wide range of feminisms, all of which found a home in the WLM, may be traced through feminist involvement with, and commitment to, publishing, print and feminist magazines.

It is vital that we continue to develop the history of the WLM. Towards this end a conference was held at the University of Portsmouth in July 2014, 'Situating Women's Liberation, Historicizing a Movement'. This collection of papers has been developed from that conference. The aim of the conference was to bring new discussions of the WLM to the fore, sometimes introducing new perspectives, and sometimes recasting existing debates in a new light. The WLM represents an important moment of consciousness-raising and self-expression for a wide range of women across the world, and therefore is a crucial movement in the history of the feminist journey towards gender equality. Feminist writers of the WLM have themselves chosen to consider further contexts for, and offer new perspectives on, their earlier writings. ${ }^{12}$ The original essays in this collection also help us to 
broaden our understanding of the impact and implication of the WLM and therefore make a valuable addition to WLM historiography.

\section{Notes}

\footnotetext{
${ }^{1}$ Stephanie Gilmore (2013) Groundswell: Grassroots Feminist Activism in Post War America (London: Routledge), p. 129; Celia Hughes (2012) Realigning political and personal selfhood: narratives of activist women in the late 1960s and 1970s, Women's History Magazine, Issue 68, Spring 2012.

${ }^{2}$ Gilmore, Groundswell, P. 19.

${ }^{3}$ Carol Giardina (2010) Freedom for Women, Forging the Women's Liberation Movement 1953-70 (USA: University of Florida), p5, p. 12, p. 116, p. 214. For the UK see Natalie Tomlinson (2012) The Colour of Feminism: White Feminists and Race in the Women's Liberation Movement, History, vol 97, pp. 453-475. ${ }^{4}$ Becky Thompson (2002) Multiracial Feminism: Recasting the Chronology of Second Wave Feminism, Feminist Studies, vol. 28 no 2, p. 337.

${ }^{5}$ See Lela Fernandez (2010) Unsettled “Third Wave Feminism”, Feminist Waves, Intersectionality and Identity Politics in Retrospect, in Nancy Hewitt (Ed.) No Permanent Waves, Recasting Histories of US Feminism (New Jersey, USA: Rutgers University Press), pp. 98-112.

${ }^{6}$ Thompson, 'Multiracial Feminism', p. 338.

${ }^{7}$ Hewitt, ed., No Permanent Waves, pp. 1-7.

${ }^{8}$ Giardina, Freedom for Women, p. 231.

${ }^{9}$ Constance Backhouse \& David H. Flaherty (Eds) (1992) Challenging Times, The Women's Movement in Canada and the US (Montreal, Canada: McGill), Introduction, p. 5.

${ }^{10}$ For Consciousness Raising in the UK, see Sue Bruley (2013) Consciousness Raising in Clapham, Women’s Liberation as "Lived Experience” in South London in the 1970s, Women's History Review, Vol.22, Issue 5, pp. 717-738.

${ }^{11}$ Beatrix Campbell \& Anne Coote (1982) Sweet Freedom, The Struggle for Women's Liberation, (London: Pan), pp. 204-5. See also Women's Voice May 1979, p. 5 for details of sixteen women who came to trial in April 1979 following arrests at a Reclaim the Night demonstration the previous November.

${ }^{12}$ Sheila Rowbotham, Lynne Segal \& Hilary Wainwright (2013) Beyond the Fragments: Feminism and the Making of Socialism, $3^{\text {rd }}$ edn, first published 1979 (Pontypool: The Merlin Press).
} 